E3S Web of Conferences 1, 12004 (2013)

DOI: $10.1051 / \mathrm{e} 3$ sconf/20130112004

(c) Owned by the authors, published by EDP Sciences, 2013

\title{
Histopathological Effects of Mercury on Male Gonad and Sperm of Tropical Fish Gymnotus carapo in vitro
}

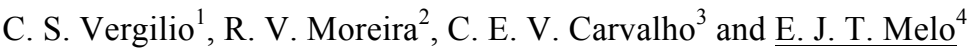 \\ ${ }^{1}$ Universidade Estadual do Norte Fluminense, Centro de Biociências e Biotecnologia, Laboratório de Biologia Celular e \\ Tecidual, Campos dos Goytacazes, RJ, 28013-602, Brazil, cristianesvergilio@gmail.com \\ ${ }^{2}$ Universidade Estadual do Norte Fluminense, Centro de Biociências e Biotecnologia, Laboratório de Biologia Celular e \\ Tecidual, Campos dos Goytacazes, RJ, 28013-602, Brazil, renata_vasconcellos@yahoo.com.br \\ ${ }^{3}$ Universidade Estadual do Norte Fluminense, Centro de Biociências e Biotecnologia, Laboratório de Ciências \\ Ambientais, Campos dos Goytacazes, RJ, 28013-602, Brazil, carvalho@uenf.br \\ ${ }^{4}$ Universidade Estadual do Norte Fluminense, Centro de Biociências e Biotecnologia, Laboratório de Biologia Celular e \\ Tecidual, Campos dos Goytacazes, RJ, 28013-602, Brazil, ejtm1202@gmail.com
}

\begin{abstract}
Hg}$ is toxic metal mostly due to adverse effects on structure and function of tissues and organs in humans and animals. Male reproductive systems of fish species are also sensitive to Hg action. However, the histological alterations in tropical fish testis are less known and little information is available concerning the underlying mechanisms of metal pathogenesis in reproductive functions. Further investigations dealing with $\mathrm{Hg}$ direct effects on tissue and organs of tropical species are a need. The present study investigated $\mathrm{HgCl}_{2}$ toxic effects in testes and sperms of tropical fish Gymnotus carapo. The histopathology, germ cell structure and number were analysed to elucidate the pathological process during exposure to increasing metal concentrations $(1 \mu \mathrm{M}-30 \mu \mathrm{M})$. Fishes exposed to $20 \mu \mathrm{M}$ and $30 \mu \mathrm{M}$ reached testicular $\mathrm{Hg}$ concentrations of $5.1 \mu \mathrm{g} \cdot \mathrm{g}^{-1}$ and 5.2 $\mu \mathrm{g} . \mathrm{g}^{-1}$, respectively. No significant alterations in gonadosomatic index (GSI) occurred between control, and $\mathrm{Hg}$ exposed fishes. Untreated fishes showed characteristic organization of testicular tissue, with germ epithelium organized in cysts where spermatogenesis occurs. Germ cells and spermatozoa are seen an inner the cysts. $\mathrm{HgCl}_{2}$ induced severe damages characterized by complete disorganization of seminiferous lobules, proliferation of interstitial tissue, congestion of blood vessels, reduction of germ cells and sperm aggregation. Exposed fishes showed a decrease in the sperm's number. Initial reduction of a sperm's number $(36,8 \%)$ was observed after $20 \mu \mathrm{M} / 24 \mathrm{~h}$ treatment and subsequent decrease $(48,7 \%)$ was obse rved after $20 \mu \mathrm{M} / 96 \mathrm{~h} . \mathrm{Hg}$ $(20 \mu \mathrm{M})$ also altered sperm morphology in $24 \mathrm{~h}$ and $96 \mathrm{~h}$ where sperm head abnormalities were present. In conclusion, the present study showed $\mathrm{HgCl}_{2}$ progressive damages in testicular tissue, sperm count and morphology of tropical species Gymnotus carapo. The effects in testicular tissues were observed since low $\mathrm{Hg}$ concentrations. These results are important to establish a direct correlation between the mercury accumulation and severity of lesions.
\end{abstract}

Key words: Heavy metal, Hg effects, morphology, spermatozoa, testes

\section{Introduction}

Mercury $(\mathrm{Hg})$ is a toxic environment pollutant that induces several adverse effects in many tissues and organs of humans and animals. Male reproductive system is also sensitive to $\mathrm{Hg}$ (Boujbiha et al., 200). In fishes, $\mathrm{Hg}$ can inhibit gametogenesis, induce testicular atrophy, and impair individual reproduction. Despite some of $\mathrm{Hg}$ induced damages are known, there is still less information about the metal accumulation on tissue and its relationship with ultrastructure disorganization of fish testis, especially for tropical species.

Sperms are also useful in assessing the $\mathrm{Hg}$ impacts on male reproductive system. In rodents, acute contamination decreased reproductive quality of gametes, where sperm morphology, count, motility and viability were affected. Further investigations in such parameters are needed for different fish species since they may dramatically decrease sperm performance in aquatic environment affecting fertilization success and alter fish populations.

Gymnotus carapo (tuvira) is a tropical freshwater 
fish widely distributed in South American. It easily maintained in experimental conditions, being an interesting model to evaluate toxic effects of pollutants in Brazilian ecosystems.

In the present study, the $\mathrm{HgCl}_{2}$ toxic effects in testes and sperms of a teleost Gymnotus carapo were observed, elucidating the pathological process during in vitro exposure to increasing concentrations $(1 \mu \mathrm{M}-30 \mu \mathrm{M})$.

\section{Materials and Methods}

\section{Fish contamination}

Gymnotus carapo specimens $(\mathrm{n}=116)$ used in the present study were all male in same sexual maturity stage, obtained from Cima Lake, northern of Rio de Janeiro state $\left(21^{\circ} 46^{\prime} \mathrm{S}\right.$ e $\left.41^{\circ} 31^{\prime} \mathrm{W}\right)$. Heavy metal's distribution in sediments and biota of Cima Lake has already been described and characterized as area with low levels of metal pollution (Ferreira et al., 2003).

For each $\mathrm{HgCl}_{2}$ contamination, 6 male adult fish were selected, four exposed to $\mathrm{HgCl}_{2}$ concentrations (5 $\mu \mathrm{M} / 10 \mu \mathrm{M} / 20 \mu \mathrm{M} / 30 \mu \mathrm{M})$ and two kept as the control group. The fishes were exposed at different exposure times $(24 \mathrm{~h} / 48 \mathrm{~h} / 72 \mathrm{~h} / 96 \mathrm{~h})$ and control fishes were always dissected in $24 \mathrm{~h}$ and $96 \mathrm{~h}$ of exposure. In order to increase the sampling for chemical and histological analysis the procedure was repeated consecutive times for each time/concentration tested.

Contamination was achieved by intraperitoneal injection of $\mathrm{HgCl}_{2}$ solution while the control group was injected with phosphate buffer solution. To avoid differences in treatment, all fish used for this study were of similar size (length: $32 \pm 1 \mathrm{~cm} /$ weight: $125.8 \pm 17.8 \mathrm{~g}$ ). After each exposure time, the specimens were measured, weighed and dissected to obtain testis for further analysis.

\section{Hg chemical determination in the testes}

For mercury detection, testis samples from control and contaminated fishes followed strong acid digestion according to methodology described by Bastos et al. (1998). All the $\mathrm{Hg}$ determinations were performed by spectroscopy of atomic emission method using the equipment ICP-AES (Varian, Liberty II models) with cold vapor accessory (VGA-77). The method limit detection was calculated according to Skoog and Leary (1992) as being of $0.23 \mu \mathrm{g} \cdot \mathrm{g}^{-1}$.

\section{Analysis of testis morphology}

Samples of control and $\mathrm{Hg}$ exposed testis were fixed in $10 \%$ neutrally buffered formalin for 24 hours. The samples were then dehydrated in a progressive series of alcohol, cleared in xylene, embedded in paraffin. The samples sectioned $(5 \mu \mathrm{m})$ and stained with hematoxylin and eosin (H\&E) for examination by light microscopy. Samples of the testis (approximately $1 \mathrm{~mm}^{3}$ ) were also fixed in formaldehyde $4 \%$, glutaraldehyde $2.5 \%$, cacodylate buffer $0.1 \mathrm{M}$, sucrose $5 \%$, calcium chloride 5 $\mathrm{mM}$ and post-fixed (1:1) in osmium teroxide $1 \%$ and potassium ferricyanide $0.8 \%$, dehydrated with acetone, embedded in Epon $\AA$. Semithin slices $(0.4 \mu \mathrm{m})$ were obtained using an ultramicrotome Reichercuts Leica. Slices stained with toluidine blue $(1 \%)$ were observed with light microscopy.

\section{Sperm Sampling}

Following the damages observed in testis, $\mathrm{Hg}$ effects in sperm were evaluated in $20 \mu \mathrm{M}$ concentration after $24 \mathrm{~h}$ and $72 \mathrm{~h}$. Testis from control $(\mathrm{n}=4), \mathrm{Hg}$ exposed to 20 $\mu \mathrm{M} / 24 \mathrm{~h}(\mathrm{n}=2)$ and $20 \mu \mathrm{M} / 72 \mathrm{~h}(\mathrm{n}=2)$ were minced with anatomic scissors in $2 \mathrm{~mL}$ of cacodylate buffer $0.1 \mathrm{M}(\mathrm{pH}$ 7.2) for 5 minutes at room temperature. After dilution, the sperm's number was counted in hemocytometer under light microscopy using phase contrast at $\mathrm{x} 400$ magnification.

\section{Sperm morphology}

Seminal fluid from control and contaminated fishes were fixed in fixative solution ( $4 \%$ formaldehyde, $2.5 \%$ glutaraldehyde, $5 \%$ sucrose in $0.1 \mathrm{M}$ cacodylate buffer, $\mathrm{pH}$ 7.2). Attached in coverslip with poly-L-lysine, postfixed in osmium tetroxide $1 \%$, dehydrated in ethanol, critical-point dried in $\mathrm{CO}_{2}$ (BAL-TEC CPD 030 Critical Point Dryer) and sputtered with gold (BAL-TEC SCD 050 Sputter Coater) for observation in Zeiss Evo 40 microscopy scanning electron at $15 \mathrm{kV}$, employing secondary electrons.

\section{Statistic analysis}

All the values are expressed as mean \pm SD. Significant differences were determined with Graph-prism v.4 Software (GraphPad Software, Inc. CA, USA). Two-way analysis of variance followed by Bonferroni test was performed for $\mathrm{Hg}$ concentration's data and one-way analysis of variance followed by Tukey test was used for sperm data. Differences were considered significant when $p<0.05$.

\section{Results and Discussion}

External investigation was performed in each fish before and after the execution of the experiments. Control and $\mathrm{Hg}$ treated fishes showed to be healthy according to conditions of their gills, eyes and scales. Internal organs, as liver, kidney and especially the testis did no present macroscopic anatomic alteration.

As described in figure 1, testicular tissue in untreated fishes showed characteristic organization of cysts arrangement where spermatogenesis occurs (Fig 1a). Inner the cysts, germ cells (Fig 1b, c) in different stages of differentiation are distributed as: primary (SPGI) and secondary (SPGII) spermatogonia, primary (SPCI) and secondary (SPCI) spermatocytes and spermatids (SPD). 
These cells undergo a number of cell divisions until sperm formation inner the cysts (arrowheads) (Fig 1b, c). Between the cysts interstitial tissue (it) is present being composed by Leydig cells, blood/lymphatic vessels and connective tissue (Fig 1b).

$\mathrm{Hg}$ induced changes in treated fishes for all concentrations administrated and the effects become more severe with increase of dose/time. Hg treatment induced complete disorganization in cysts arrangement (Fig 2) with congestion of blood vessels (Fig 2b) and proliferation of interstitial tissue (Fig 2b). Severe damages were observed in higher concentrations $(20 \mu \mathrm{M}$ and $30 \mu \mathrm{M}$ ) as reduction of germ cells (Fig 2d), marked variations of cyst size (Fig 2c), interstitial and lobular disintegration (Fig 2d), sperm aggregation (Fig 2c).

$\mathrm{Hg}$ chemical analysis revealed that treated fishes with $20 \mu \mathrm{M}$ and $30 \mu \mathrm{M}$ reached highest testicular concentrations of $5.1 \mu \mathrm{g} . \mathrm{g}^{-1}$ and $5.2 \mu \mathrm{g} . \mathrm{g}^{-1}$, respectively (Table 1). Hg concentrations in control and treated with $5 \mu \mathrm{m}, 10 \mu \mathrm{m}$ were bellow the detection limits of the method (Table 3). These results are in agreement with severe damages observed by histopathological analysis and indicate that even low $\mathrm{Hg}$ doses can induce morphological alterations in testis.

The present study also enhances the knowledge about progressive accumulation of $\mathrm{HgCl}_{2}$ and adverse effects in testicular tissue structure. In important point, this study showed that histology damages started at concentrations not detectable by the limit of accumulation method ( $<$ detection limit). These results are important to establish a direct correlation between the mercury accumulation and the severity of tissue lesions (Boujbiha et al. 2009).

$\mathrm{Hg}$ induced severe damages in testis arrangement, affecting the germ cells that are involved in spermatogenesis process. Therefore, investigations in sperms were also performed for overall evaluation of $\mathrm{Hg}$ effects in male gonad.

$\mathrm{Hg}$ affected sperms count (Fig 3) in a timedependent matter. Significant reduction (36.8\%) of sperms number was observed after treatment with 20 $\mu \mathrm{M} / 24 \mathrm{~h}$ (Fig 3). A subsequent reduction (48.7\%) was observed in same concentration treatment $(20 \mu \mathrm{M})$ for 96h (Fig 3).
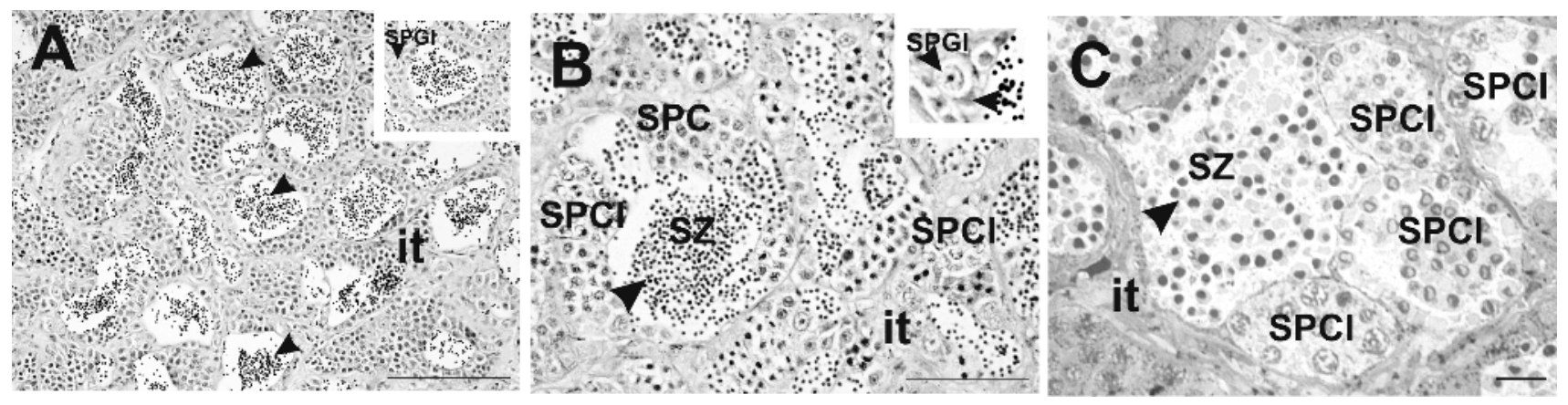

Fig 1. Normal morphology of Gymnotus carapo testis. (A) Testicular organization with seminiferous lobes (inset) and interstitial tissue (it). (B) and (C) Seminiferous lobes containing germ cells: primary spermatogonia (SGI), primary (SPCI) and secondary (SPCII) spermatocytes and spermatids (SD). Spermatozoids (SZ) are also seen within the lobe's lumen. Scale bar: A: $200 \mu \mathrm{m}(100 \mathrm{x}), \mathrm{B}: 100 \mu \mathrm{m}(200 \mathrm{x}), \mathrm{C}: 20 \mu \mathrm{m}(400 \mathrm{x})$.
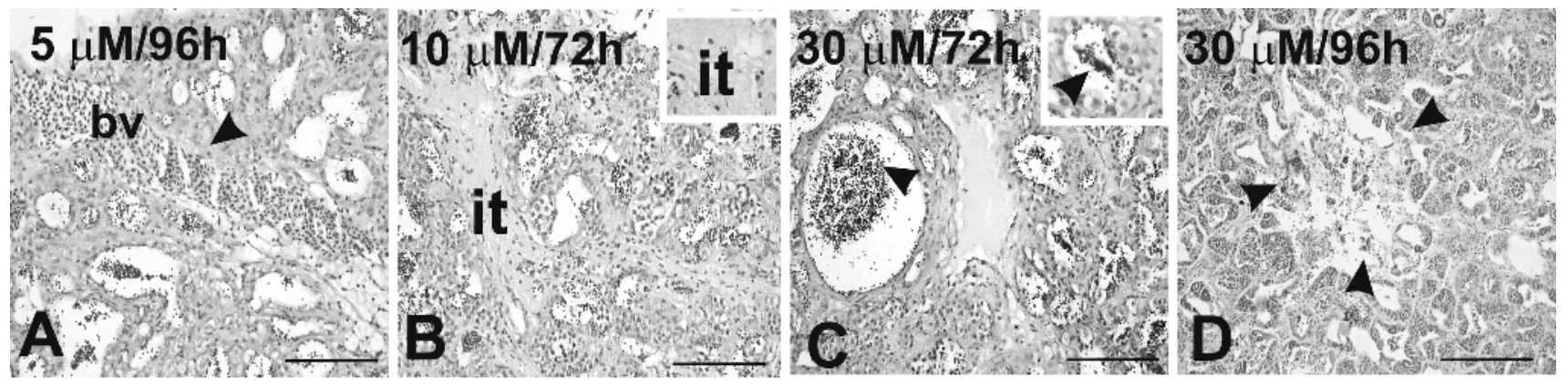

Fig 2. Gymnotus carapo testis of $\mathrm{HgCl}_{2}$ exposed fishes. After $\mathrm{Hg}$ treatment the fishes showed evident disorganization of testicular arrangement (A - D). (A) shows congestion of blood cells after $5 \mu \mathrm{M} / 96 \mathrm{~h}$ treatment. (B) Proliferation of interstitial tissue (it) (inset) is evident after $10 \mu \mathrm{M} / 72 \mathrm{~h}$. (C) shows marked variation in seminiferous lobules size and sperm aggregation after $30 \mu \mathrm{M} / 72 \mathrm{~h}$. (D) Severe damage to interstitial and lobular tissue is evident after treatment with 30 $\mu \mathrm{M} / 96 \mathrm{~h}$. Scale bar: A - D: $200 \mu \mathrm{m}$. 
Table 1. Mercury $(\mathrm{HgT})$ concentrations $\left(\mu \mathrm{g} \cdot \mathrm{g}^{-1}\right)$ in testis.

\begin{tabular}{ccccc}
\hline Treatment $\backslash$ concentration & $5 \mathrm{uM}$ & $10 \mathrm{uM}$ & $20 \mathrm{uM}$ & $30 \mathrm{uM}$ \\
\hline control & $\mathrm{nd}^{\mathrm{a}}$ & $\mathrm{nd}^{\mathrm{a}}$ & $\mathrm{nd}^{\mathrm{a}}$ & $\mathrm{nd}^{\mathrm{a}}$ \\
$24 \mathrm{~h}$ & $\mathrm{nd}^{\mathrm{a}}$ & $\mathrm{nd}^{\mathrm{a}}$ & $\mathrm{nd}^{\mathrm{a}}$ & $4.6 \pm 3.3^{\mathrm{b}}$ \\
$48 \mathrm{~h}$ & $\mathrm{nd}^{\mathrm{a}}$ & $\mathrm{nd}^{\mathrm{a}}$ & $4.7 \pm 1.7^{\mathrm{b}}$ & $4.1 \pm 1.7^{\mathrm{b}}$ \\
$72 \mathrm{~h}$ & $\mathrm{nd}^{\mathrm{a}}$ & $\mathrm{nd}^{\mathrm{a}}$ & $5.1 \pm 2.5^{\mathrm{b}}$ & $5.2 \pm 2.8^{\mathrm{b}}$ \\
$96 \mathrm{~h}$ & $\mathrm{nd}^{\mathrm{a}}$ & $\mathrm{nd}^{\mathrm{a}}$ & $3.6 \pm 0.7^{\mathrm{a}}$ & $3.2 \pm 1.1^{\mathrm{a}}$ \\
\hline
\end{tabular}

$\boldsymbol{n d}$ : not detected by equipment since concentrations bellow limit of method detection. The letters $\mathrm{a}, \mathrm{b}$ indicate the indicate groups at means that are significant different at $5 \%$ of significance level.

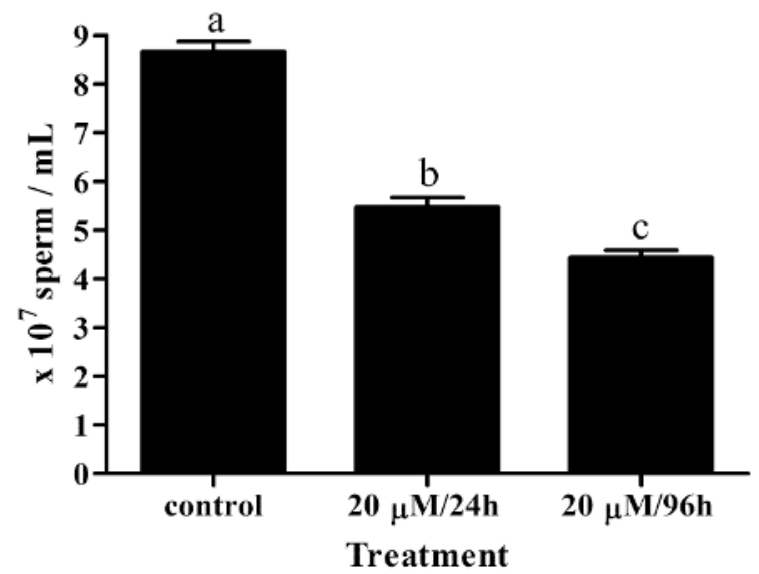

Fig. 3. Effect of mercury on sperm count after $20 \mu \mathrm{M}$ treatment for different exposure times (24h and $96 \mathrm{~h}$ ). The letters $\mathrm{a}, \mathrm{b}$ and $\mathrm{c}$ indicate that are significant different at $5 \%$ of significance level.

Ultrastructural features of sperm cell were drastically altered after $\mathrm{Hg}$ exposure (Fig 4). G. carapo sperm have an ovoid shape head, midpiece and flagellum (Fig 4a) as observed in control fishes. Both $20 \mu \mathrm{M}$ treatments for $24 \mathrm{~h}$ and $96 \mathrm{~h}$ induced changes in sperm head (Fig 4b - d, arrows).
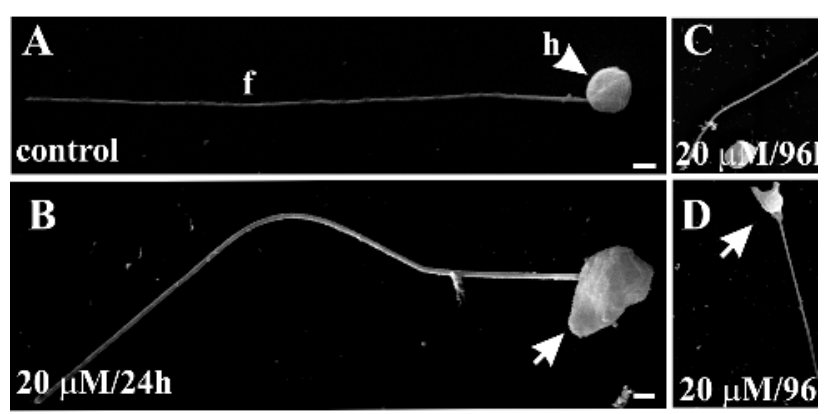

Fig. 4. Changes in morphology of Gymnotus carapo spermatozoa after $\mathrm{HgCl}_{2}$ treatment demonstrated by scanning electron microscopy.

\section{Conclusion}

The present study showed $\mathrm{HgCl}_{2}$ progressive damages in testicular pathology, sperm count and morphology of tropical fish species Gymnotus carapo. These results are important to establish a direct correlation between the $\mathrm{Hg}$ accumulation and the severity of lesions since the testis analysis was performed since $\mathrm{Hg}$ concentrations bellow limit of method detection until higher doses that induced severe damages. Moreover, this work enhances the data about $\mathrm{Hg}$ toxicological effect in fishes from tropical regions.

\section{Acknowledgments}

This work was supported by Fundação Carlos Chagas Filho de Amparo à Pesquisa do Estado do Rio de Janeiro (E-26/171.315/2004) (E-26/ 100.470/2007) (E26/110.921/2008).

\section{References}

Bastos WR, Malm O, Pfeiffer WC, Cleary D (1998) Establishment and analytical quality control of laboratories for $\mathrm{Hg}$ determination in biological and geological samples in the Amazon, Brazil. Ciência e Cultura 50: 255-260

Boujbiha MA, Hamden K, Guermazi F, Bouslama A, Omezzine A, Kammoun A, Feki AE (2009) Testicular toxicity in mercuric chloride treated rats: Association with oxidative stress. Reprod Toxicol 28: 81-89.

Crump KL, Trudeau VL (2009) Mercury-induced reproductive impairment in fish. Environ Toxicol Chem 28: 895-907.

Ferreira AG, Melo EJT, Carvalho, CEV (2003) Histological aspects of mercury contamination in muscular and hepatic tissues of Hoplias malabaricus (Pisces, Erytrinidae) from lakes in the north of Rio de Janeiro State, Brazil. Acta Microscopica 12: 49-54.

Skoog DA, Leary JJ (1992) Principles of Instrumental Analysis. Saunders College Publishing Orlando. Florida. 